\title{
Exploring virtual collaborative writing in the EFL classroom
}

\author{
Antonio Martínez-Sáez ${ }^{1}$, Avelino Corral-Esteban², \\ and Margarita Vinagre-Laranjeira ${ }^{3}$
}

\begin{abstract}
With the integration of new technologies in the foreign language classroom, the practice of collaborative writing has gained renewed attention, although some questions still remain unanswered regarding the extent to which these tools help learners in their writing when compared to more traditional learning contexts (Elola \& Oskoz, 2010). In order to explore these issues, we analysed the written production of 84 undergraduate students of English as a Foreign Language (EFL) using the LIWC2015 ${ }^{4}$ software. The analysis revealed significant differences in categories such as word count, clout, emotional tone, or analytical thinking when comparing the texts written by an experimental and a control group. Moreover, regarding discourse, some differences were observed in terms of the way information was presented and structured.
\end{abstract}

Keywords: language learning, collaborative writing, virtual collaboration, discourse analysis.

\section{Introduction}

The effects of collaborative writing - "the co-authoring of a text by two or more writers" (Storch, 2013, p. 2) - has become the focus of much research in recent years. Some studies suggest "that collaborative writing promotes reflective thinking,

\footnotetext{
1. Universidad Politécnica de Madrid, Madrid, Spain; antonio.martinezs@upm.es

2. Universidad Autónoma de Madrid, Madrid, Spain; avelino.corral@uam.es

3. Universidad Autónoma de Madrid, Madrid, Spain; margarita.vinagre@uam.es

4. Linguistic Inquiry and Word Count. Software published by Pennebaker Conglomerates, Inc, Austin, TX, USA. For more information go to http://liwc.wpengine.com/how-it-works/

How to cite this article: Martínez-Sáez, A., Corral-Esteban, A., \& Vinagre-Laranjeira, M. (2018). Exploring virtual collaborative writing in the EFL classroom. In P. Taalas, J. Jalkanen, L. Bradley \& S. Thouësny (Eds), Future-proof CALL: language learning as exploration and encounters - short papers from EUROCALL 2018 (pp. 188-192). Research-publishing.net. https://doi.org/10.14705/rpnet.2018.26.835
} 
focusses attention on grammatical accuracy, lexis, and discourse, and encourages a pooling of knowledge about language" (Donato, 1994; Storch, 2013, cited in Oskoz \& Elola, 2011, p. 209). In order for collaborative writing to be successful, some authors have mentioned that students have to become truly involved and engaged in the activity (e.g. Oskoz \& Elola, 2011).

However, there are still some unanswered questions regarding the differences between the process of collaborative writing in more traditional contexts and in those in which technology has been integrated in the classroom. We are referring more specifically to telecollaborative environments, which are gaining renewed attention and becoming more relevant among researchers who study their effects on collaborative writing (Elola \& Oskoz, 2010). In this study, we have used the term telecollaboration to refer to an activity in which students, who are in faceto-face environments, use technologies to collaborate (Vinagre, 2016). In its more strict sense, this activity refers to students who are located in different countries and use technologies to carry out tasks or project work together.

Given its potential, in this study we analyse the collaboratively written production of a group of students who worked in this environment (experimental group) and that of another group who wrote collaboratively in class (control group).

\section{Complexity, accuracy, fluency, and discourse analysis}

Complexity, accuracy, and fluency "represent three dimensions of L2 production" and are "of value to L2 language teachers as they can use the research findings to improve their practice and their students' language performance" (Craven, 2017, p. 25). In general terms and in line with Craven's (2017) definitions, complexity is seen as "the use of more challenging and difficult language"; accuracy as "the degree of conformity to certain language usage norms", primarily in lexicon and grammar; and fluency as "a person's general language proficiency in relation to ease and smoothness of speech or writing” (p. 25).

In order to compare the written production of both groups, we decided to use LIWC2015 software since some of the variables it measures (see below) are based on the complexity and fluency factors mentioned above. Besides, the software also analyses other relevant features for this study - including cohesive devices such as reference, repetition, substitution, ellipsis, conjunction, and connectors (Schiffrin, 2001). 


\section{Method}

Eighty-four first year students of English at Autónoma University of Madrid participated in this study. Their levels of proficiency in the foreign language ranged from a B1 to a $\mathrm{C} 1$ (all according to the Common European Framework of Reference for Languages).

Students were divided randomly into two groups. Students in the experimental group used Google Docs as a technological tool to write a joint collaborative essay based on a list of suggested topics working in small groups. Similarly, students in the control group used pen and paper to carry out the same task also working in small groups. Eleven texts in total were produced by the experimental and the control group respectively.

The texts were then introduced in LIWC2015. This tool processes text files and displays categories such as word count, analytical thinking, clout, authentic, emotional tone, words per sentence, words including more than six letters, the total number of function words, etc. Furthermore, as explained on this software's website, "the text analysis module [...] compares each word in the text against a user-defined dictionary"5. Most of its output variables are expressed as percentage of total words, with the exception of Word Count (WC; raw word count), mean Words Per Sentence (WPS), and four summary variables: analytic, clout, authentic, and tone. These summary variables are "standardised composites which have been converted to percentiles based on large corpora of texts described in the LIWC2015 Language Manual" (Pennebaker, Booth, Boyd, \& Francis, 2015, pp. 6-7).

\section{Results and discussion}

The results show that there were some significant differences between the texts produced by both groups in some of the categories analysed by LIWC2015. For instance, the total number of words written by the students in the experimental group was 2,452 , whereas the control group wrote only 1,451. The group working in the virtual environment also obtained higher results in the following categories (definitions available from Pennebaker et al., 2015, p. 22): clout, which reflects "a higher level of expertise and confidence" (experimental group: 93.21 / control group: 80.73); tone, which is "associated with a more positive and upbeat style" (experimental: 77.55 / control: 12.87); and function words (experimental: 52.98 / control: 50.03).

5. http://liwc.wpengine.com/how-it-works/ 
In contrast, as illustrated in Table 1, the control group achieved higher results in other categories such as analytical thinking, i.e. "more formal, logical, and hierarchical thinking", and authentic, associated with "a more honest, personal, and disclosing text" (Pennebaker et al., 2015, p. 22).

Table 1. Results of the analysis of the rest of variables

\begin{tabular}{|l|l|l|l|l|}
\hline & Analytic & Authentic & Words/sentence & Words > 6 letters \\
\hline Control group & 83.33 & 13.33 & 17.91 & 21.23 \\
\hline Experimental group & 45.89 & 5.99 & 13.78 & 18.11 \\
\hline
\end{tabular}

These results suggest that students in the experimental group tended to be more productive, showed a higher level of expertise, and felt more confident and positive. However, students in the control group preferred to adopt a more formal and personal approach to the task. Besides, they wrote longer and more complex words. A plausible explanation for these findings could be that students in the control group tended to focus more on the task itself, on what and how they wrote it, and at the same time they reflected more on the format and wording of their final joint essay. The experimental group, on the other hand, seemed to focus more on the collaborative interaction than on the task, as can be deduced from their levels of confidence and positivity (Vinagre \& Corral, 2017).

As regards discourse analysis tokens, some differences were observed in terms of the way information was presented and structured. As already mentioned, students in the control group tended to focus mostly on formal aspects, such as a more frequent and accurate use of cohesive devices and adequate paragraph separation, whereas those in the experimental group focussed more on content and included a higher number of new relevant ideas related to the topic of their essays. In this respect, it is possible that by giving priority to the collaborative interaction over the task, the students in the experimental group feel freer to explore and discuss other relevant ideas that can enrich their task.

\section{Conclusions}

The findings suggest that the students in the control group were more focussed on the variables based on complexity, which highlights the idea that they might adopt a more reflective and even cautious attitude in face-to-face interaction when having to reach agreements on the words and structure of their essays. Other factors explaining these results could be related to the importance of reinforcing and constructing a more positive and desirable personal identity. In contrast, 
students using the technological tool to write their joint essay achieved better results in the variables based on fluency. Moreover, these findings suggest that in a telecollaborative environment, students feel freer to explore, discuss, and add more ideas and thus write longer texts since they might also tend to adopt a less inhibited attitude.

\section{Acknowledgements}

This research was funded by the Spanish Ministry of Economy and Competitiveness (EDU2014-54673R).

\section{References}

Craven, L. (2017). Measuring language performance: complexity, accuracy and fluency measures. The 2017 WEI International Academic Conference Proceedings. https://www. westeastinstitute.com/wp-content/uploads/2017/02/Laurence-Craven.pdf

Donato, R. (1994). Collective scaffolding in second language learning. In J. Lantolf \& G. Appel (Eds), Vygotskian approaches to second language research (pp. 33-56). Ablex.

Elola, I., \& Oskoz, A. (2010). Collaborative writing: fostering foreign language and writing conventions development. Language Learning \& Technology, 14(3), 30-49.

Oskoz, A., \& Elola, I. (2011). Meeting at the Wiki: the new arena for collaborative writing in foreign language courses. In M. J. Lee \& C. McLoughlin (Eds), Web 2.0-based e-learning: applying social informatics for tertiary teaching. Information Science Reference. https://doi. org/10.4018/978-1-60566-294-7.ch011

Pennebaker, J. W., Booth, R. J., Boyd, R. L., \& Francis, M. E. (2015). Linguistic inquiry and word count: LIWC2015 Operator's Manual. Pennebaker Conglomerates.

Schiffrin, D. (2001). Discourse markers: language, meaning, and context. In D. Schiffrin, D. Tannen \& H. E. Hamilton (Eds), The handbook of discourse analysis. Blackwell Publishers.

Storch, N. (2013). Collaborative writing in L2 classrooms. Multilingual Matters. https://doi. org/10.21832/9781847699954

Vinagre, M. (2016). Developing key competences for life-long learning through virtual collaboration: teaching ICT in English as a medium of instruction. In C. Wang \& L. Winstead (Eds), Handbook of research on foreign language education in the digital age (pp. 170-187). IGI Global. https://doi.org/10.4018/978-1-5225-0177-0.ch008

Vinagre, M., \& Corral, A. (2017). Evaluative language for rapport building in virtual collaboration: an analysis of appraisal in computer-mediated interaction. Language and Intercultural Communication, 18(3), 335-350. https://doi.org/10.1080/14708477.2017.1378227 


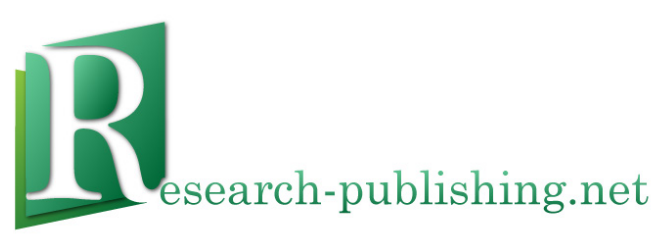

Published by Research-publishing.net, a not-for-profit association Contact: info@research-publishing.net

(C) 2018 by Editors (collective work)

(C) 2018 by Authors (individual work)

Future-proof CALL: language learning as exploration and encounters - short papers from EUROCALL 2018 Edited by Peppi Taalas, Juha Jalkanen, Linda Bradley, and Sylvie Thouësny

\section{Publication date: 2018/12/08}

Rights: the whole volume is published under the Attribution-NonCommercial-NoDerivatives International (CC BYNC-ND) licence; individual articles may have a different licence. Under the CC BY-NC-ND licence, the volume is freely available online (https://doi.org/10.14705/rpnet.2018.26.9782490057221) for anybody to read, download, copy, and redistribute provided that the author(s), editorial team, and publisher are properly cited. Commercial use and derivative works are, however, not permitted.

Disclaimer: Research-publishing.net does not take any responsibility for the content of the pages written by the authors of this book. The authors have recognised that the work described was not published before, or that it was not under consideration for publication elsewhere. While the information in this book is believed to be true and accurate on the date of its going to press, neither the editorial team nor the publisher can accept any legal responsibility for any errors or omissions. The publisher makes no warranty, expressed or implied, with respect to the material contained herein. While Researchpublishing.net is committed to publishing works of integrity, the words are the authors' alone.

Trademark notice: product or corporate names may be trademarks or registered trademarks, and are used only for identification and explanation without intent to infringe.

Copyrighted material: every effort has been made by the editorial team to trace copyright holders and to obtain their permission for the use of copyrighted material in this book. In the event of errors or omissions, please notify the publisher of any corrections that will need to be incorporated in future editions of this book.

Typeset by Research-publishing.net

Cover theme by (C) 2018 Antti Myöhänen (antti.myohanen@gmail.com)

Cover layout by (C) 2018 Raphaël Savina (raphael@savina.net)

Drawings by (C) 2018 Linda Saukko-Rauta (linda@redanredan.fi)

ISBN13: 978-2-490057-22-1 (Ebook, PDF, colour)

ISBN13: 978-2-490057-23-8 (Ebook, EPUB, colour)

ISBN13: 978-2-490057-21-4 (Paperback - Print on demand, black and white)

Print on demand technology is a high-quality, innovative and ecological printing method; with which the book is never 'out of stock' or 'out of print'.

British Library Cataloguing-in-Publication Data.

A cataloguing record for this book is available from the British Library.

Legal deposit, UK: British Library.

Legal deposit, France: Bibliothèque Nationale de France - Dépôt légal: Décembre 2018. 